\title{
EFFECT OF EDUCATION AND TRAINING (DIKLAT / BIMTEK), UNDERSTANDING OF REGIONAL FINANCIAL ACCOUNTING SYSTEMS (SIMDA) ON PERFORMANCE OF REGIONAL FINANCIAL MANAGEMENT
}

\section{PENGARUH PENDIDIKAN DAN PELATIHAN (DIKLAT/BIMTEK), PEMAHAMAN SISTEM AKUNTANSI KEUANGAN DAERAH (SIMDA) TERHADAP KINERJA PENGELOLA KEUANGAN DAERAH}

\author{
Nenden Restu Hidayah \\ Study Program of Accounting, Faculty of Economic, Universitas Dehasen Bengkulu \\ Email: restunenden@gmail.com
}

\begin{abstract}
How to Cite :
Hidayah, N.R. (2020). Pengaruh Pendidikan Dan Pelatihan (Diklat/Bimtek), Pemahaman Sistem Akuntansi Keuangan Daerah (SIMDA) Terhadap Kinerja Pengelola Keuangan Daerah. Bima Journal: Bussines Managemet and Accounting, 1(1).
\end{abstract}

ARTICLE HISTORY

Received [19-01-2020]

Revised [21-01-2020]

Accepted [28-02-2020]

\section{KEYWORDS}

Understanding of

Simda, Education

and Training,

Organizational

Commitment

This is an open access article under the CCBY-SA license

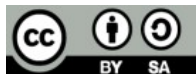

\section{ABSTRAK}

Penelitian ini menguji pengaruh Pendidikan dan Pelatihan (Diklat/Bimtek), Pemahaman Sistem Akuntansi Keuangan daerah (Simda) terhadap Kinerja pengelola keuangan daerah. Penelitian ini dilakukan terhadap 60 orang Pengelola keuangan daerah di 33 Satuan Kerja Perangkat Daerah (SKPD) Pemerintah daerah Kota Bengkulu. Penelitian ini mengumpulkan data dengan memberikan kuesioner kepada responden. Data penelitian diolah dengan menggunakan program SPSS.

Hasil penelitian membuktikan bahwa Pendidikan dan Pelatihan (Diklat/Bimtek), Pemahaman Sistem Akuntansi Keuangan daerah (Simda) berpengaruh positif Kinerja pengelola keuangan daerah. Ini membuktikan bahwa semakin baik pengelolaan yang dilakukan oleh pemerintah daerah terhadap Diklat/Bimtek, pemahaman Simda yang dimiliki oleh para pengelola keuangan daerah yang ada di SKPD maka akan semakin baik Kinerja pengelola keuangan daerah. Pemerintah daerah Kota Bengkulu untuk terus memperbaiki model Diklat/Bimtek yang ada, bersama-sama dengan meningkatkan pemahaman terhadap Simda terhadap SKPD pemerintah daerah.

\begin{abstract}
This study examines the effect of Education and Training (Diklat / Bimtek), Understanding of the Regional Financial Accounting System (Simda) on the Performance of regional financial managers. This research was conducted on 60 regional financial managers in 33 Regional Government Work Units (SKPD) Bengkulu City Government. This study collected data by giving questionnaires to respondents. Research data were processed using the SPSS program.

The results of the study prove that Education and Training (Diklat / Bimtek), Understanding of the Regional Financial Accounting System (Simda) has a positive effect on the performance of regional financial managers. This proves that the better the management carried out by the regional government towards Diklat / Bimtek, the understanding of Simda which is owned by the regional financial managers in the SKPD, the better the performance of regional financial managers. Bengkulu City regional government to continue to improve the existing Diklat I Bimtek model, together with increasing understanding of Simda towards local government SKPD.
\end{abstract}

\section{PENDAHULUAN}

Penerapan otonomi daerah telah berubah semakin maju setelah disahkannya Undang-Undang Nomor 32 Tahun 2004 mengenai Pemerintahan Daerah dan Undang-Undang Nomor 33 Tahun 2004 mengenai Perimbangan Keuangan Antara Pemerintah Pusat dan Pemerintah Daerah. Implementasi Undang-Undang ini memberikan kekuasaan dan keleluasaan kepada daerah untuk 
mengurus dirinya sendiri dengan menggali potensi daerah guna pelaksanaan pembangunan yang akhirnya mensejahterakan rakyat.

Pendidikan dan pelatihan (diklat/bimtek) pegawai merupakan kegiatan pengembangan sumber daya manusia untuk meningkatkan pengetahuan, kemampuan dan keterampilan, serta meningkatkan kinerja pegawai. Program Diklat/bimtek berupaya mengembangkan kemampuan intelektual dan kepribadian pegawai dalam pengelolaan keuangan daerah.

Faktor lain yang diduga mempengaruhi terhadap peningkatan kinerja pengelola keuangan daerah adalah pemahaman yang baik terhadap sistem informasi keuangan daerah (Simda) yang diimplementasikan di pemerintah daerah. Salah satu wujud penerapan pemanfaatan teknologi informasi yang dilakukan pemerintah daerah agar terwujudnya efektivitas kerja dan meningkatkan pengelolaan keuangan daerah adalah Sistem Informasi Manajemen Daerah (SIMDA). SIMDA merupakan aplikasi terpadu sebagai alat bantu pemerintah daerah yang digunakan meningkatkan efektivitas implementasi dari berbagai regulasi bidang pengelolaan keuangan daerah yang berdasarkan pada asas efisiensi, ekonomis, efektif, transparan, akuntabel, dan auditable yang terjadi dalam pengelolaan keuangan daerah pada tingkat Satuan Kerja Perangkat Daerah (SKPD).

Penelitian ini akan dilakukan di pemerintah daerah Kota Bengkulu. Pemilihan objek penelitian ini didasarkan pada fenomena bahwa informasi yang didapatkan pada bagian keuangan SKPD di lingkungan pemerintah daerah kota Bengkulu, dikatakan kinerja pengelola keuangan belum menunjukkan kondisi yang optimal, antara lain dari sejumlah SKPD masih belum mampu merealisasikan pekerjaan sesuai dengan target yang ditetapkan.

\section{LANDASAN TEORI}

\section{Teori Stewardship}

Dasar dari teori stewardship adalah pengambaran situasi dimana para manajer tidak termotivasi dari tujuan-tujuan individu tetapi lebih ditujukan pada sasaran hasil utama mereka untuk kepentingan organisasi, dalam kata lain teori ini mempunyai dasar psikologi dan sosiologi yang telah dirancang dimana para eksekutif sebagai steward termotivasi untuk bertindak sesuai keinginan principal. sisilainnya perilaku steward tidak mungkin meninggalkan organisasi yang ada tetapi steward berusaha mencapai sasaran organisasinya. Bayak peneliti yang menggunakan teori ini untuk menguji situasi dimana para eksekutif dalam perusahaan sebagai pelayan dapat termotivasi untuk bertindak dengan cara terbaik pada principal-nya (Donaldson dan Davis, 1994).

\section{Kinerja Pengelola Keuangan Daerah}

Kinerja adalah keluaran/hasil dari kegiatan/program yang akan atau telah dicapai sehubungan dengan penggunaan anggaran dengan kuantitas dan kualitas yang terukur. Kinerja merupakan hasil evaluasi terhadap pekerjaan yang telah dilakukan dibandingkan dengan kriteria yang telah diterapkan bersama. Kinerja adalah cara perseorangan atau kelompok dari suatu organisasi menyelesaikan pekerjaan atau tugas. Kinerja menurut Bastian (2006) adalah gambaran pencapaian pelaksanaan suatu kegiatan/program/kebijakan dalam mewujudkan sasaran, tujuan, visi, dan misi organisasi. Indikator kinerja adalah ukuran kuantitatif 
dan kualitatif yang menggambarkan tingkat pencapaian suatu sasaran atau tujuan yang ditetapkan, dengan memperhitungkan indikator masukan (input), keluaran (output), hasil, manfaat, dan dampak. Sadely (1996) mengemukakan bahwa kinerja merupakan sesuatu yang dapat dicapai; prestasi yang diperlihatkan; kemampuan kerja. Dalam konteks lingkungan kerja sebuah organisasi.

\section{Pendidikan dan Pelatihan (Diklat/Bimtek)}

Menurut Wiley (2002) dalam Azhar (2007) melihat sumber daya manusia merupakan pilar penyangga utama sekaligus penggerak roda organisasi dalam usaha mewujudkan visi dan misi serta tujuan dari organisasi tersebut. Elemen organisasi berupa Sumber daya manusia yang sangat penting, maka organisasi beperan dalam pengelolaan sumber daya manusia sebaik mungkin agar dapat memberikan kontribusi secara maksimal dalam upaya pencapaian tujuan organisasi. Sebagai kesatuan, sumber daya manusia harus dipandang sebagai suatu sistem di mana tiap-tiap pegawai merupakan berfungsi untuk mencapai tujuan organisasi. Sumber daya manusia dipengaruhi dari latar belakang pendidikan yang diperoleh pegawai tersebut. Dalam kaitannya dengan kemampuan dalam pengelolaan keuangan daerah, maka lebih efektif sumber daya manusia atau pegawai keuangan pemerintah daerah yang dimiliki latar belakang pendidikan akuntansi atau manajemen.

Heidjrachman dan Husnan (2000) dalam Zahara (2008) menyatakan bahwa pelatihan merupakan proses pendidikan jangka pendek yang mempergunakan prosedur yang terorganisasikan dan sistematik yang ditujukan untuk golongan nonmanajer yang mempelajari pengetahuan teknik dan keterampilan untuk tujuan tertentu. Sedangkan Rajana HRP (2009) menjelaskan bahwa pelatihan (training) adalah tahapan kegiatan yang dilakukan oleh manajemen kepada pegawai bertujuan meningkatkan pengetahuan, kecakapan, keterampilan, keahlian dan mental para karyawan dalam melaksanakan tugas dan pekerjaan. Nitisemito (2002) dalam Nasaruddin (2008) menyatakan bahwa pelatihan (training) adalah suatu kegiatan dari perusahaan yang bermaksud untuk memperbaiki dan mengembangkan sikap, tingkah laku, keterampilan dan pengetahuan dari para karyawan sesuai dengan keinginan dari perusahaan yang bersangkutan. Untuk memenuhi tujuan dari pendidikan dan pelatihan agar dapat tercapai, hendaknya pelaksanaan pendidikan dan pelatihan didasarkan pada prinsip-prinsip pendidikan dan pelatihan. Adapun prinsip-prinsip tersebut, menurut Supratman (2005), terdiri atas beberapa hal antara lain: Prinsip kemanusiaan, Prinsip demokrasi, Prinsip penempatan orang yang tepat dalam posisi yang tepat, prinsip balas jasa yang sebanding dengan pekerjaan, prinsip kesatuan arah, prinsip kesatuan tujuan, prinsip kesatuan komando, prinsip efisiensi dan produktivitas kerja, prinsip disiplin, prinsip wewenang dan tanggung jawab.

\section{Pemahaman Sistem Akuntansi Keuangan Daerah}

Jogiyanto (2010:2) mengemukakan bahwa sistem adalah kumpulan dari elemen-elemen yang berinteraksi untuk mencapai suatu tujuan tertentu. Sistem ini mengGambarkan suatu kejadian-kejadian dan kesatuan yang nyata adalah suatu objek nyata, seperti tempat, benda, dan orang-orang yang betul-betul ada dan terjadi. Menurut Halim (2007), Akuntansi Keuangan Daerah adalah proses 
pengidentifikasian, pengukuran, pencatatan, dan pelaporan transaksi ekonomi (keuangan) dari entitas pemerintah daerah (kabupaten, kota, atau provinsi) yang dijadikan sebagai informasi dalam rangka pengambilan keputusan ekonomi yang diperlukan oleh pihak-pihak eksternal entitas entitas pemerintah daerah (kabupaten, kota, atau provinsi). Halim (2007) menjelaskan bahwa Akuntansi Keuangan Daerah merupakan proses pengidentifikasian, pengukuran, pencacatan, dan pelaporan transaksi ekonomi (keuangan) dari entitas pemerintah daerahpemda (kabupaten, kota, dan provinsi) yang dijadikan sebagai informasi dalam rangka pengambilan keputusan ekonomi yang diperlukan oleh pihak-pihak eksternal entitas pemda (kabupaten, kota, provinsi).

Sedangkan Sistem Akuntansi Keuangan Daerah menurut Bastian (2010) adalah: "Laporan pertanggungjawaban pemerintah daerah atas seluruh aktifitas keuangan dan penggunaan sumber daya ekonomis yang dipercaya dan untuk menunjukkan keuangan daerah". Sistem akuntansi pemerintah daerah secara garis besar terdiri atas empat prosedur akuntansi, yaitu prosedur akuntansi penerimaan kas, prosedur akuntansi pengeluaran kas, prosedur akuntansi selain kas, prosedur akuntansi aset tetap/barang milik daerah (Permendagri Nomor 13 tahun 2006 pasal 233). Pada dasarnya Pemerintah Daerah telah berupaya untuk menyusun laporan keuangan dengan menggunakan sistem akuntansi keuangan daerah yang diharapkan mampu mewujudkan tercapainya transparansi dan akuntabilitas. Dengan Sistem Akuntansi Keuangan Daerah (SAKD) transparansi dan akuntabilitas yang diharapkan dalam pengelolaan keuangan daerah dapat tercapai (Halim 2008:35).

Wilkinson (1992) mengatakan bahwa sistem adalah suatu kerangka kerja terpadu yang mempunyai satu sasaran atau lebih. Sistem adalah sekelompok elemen-elemen yang terintegrasi dengan maksud yang sama untuk mencapai suatu tujuan. Informasi adalah data yang telah diolah menjadi bentuk yang berarti bagi penerimanya dan bermanfaat dalam mengambil keputusan saat ini atau mendatang, sedangkan informasi menurut Wilkinson (1992) merupakan komoditas vital bagi sebuah organisasi atau Pemerintah daerah, yang terdiri dari data yang telah ditransformasikan dan dibuat lebih bernilai melalui pemrosesan.

Sistem informasi manajemen adalah suatu sistem yang bersifat menyeluruh, bertujuan untuk menyajikan informasi yang jauh lebihluas daripada informasi akuntansi yang bersifat historis (Widjayanto, 2001). Sistem informasi manajemen yang selalu menggunakan teknologi pengolahan data elektronik, dengan menggunakan teknologi komputer maka tingkat efisiensi pekerjaan akan semakin meningkat. Lebih jauh lagi sistem informasi manajemen dapat mengkomunikasikan seluruh output yang dihasilkan dari masing-masing subsistem yang kemudian diintegrasikan menjadisebuah informasi yang diperlukan bagi manajemen dalam pengambilan keputusan.

\section{Hipotesis}

Hipotesis dalam penelitian ini adalah:

H1: Diduga Pendidikan dan Pelatihan (diklat/bimtek) mempunyai pengaruh positif terhadap kinerja pengelola keuangan daerah.

H2: Diduga Pemahaman Sistem Akuntansi Keuangan Daerah mempunyai pengaruh positif terhadap Kinerja Pengelola Keuangan SKPD 


\section{Kerangka Penelitian}

\section{Gambar 1. Kerangka Penelitian}

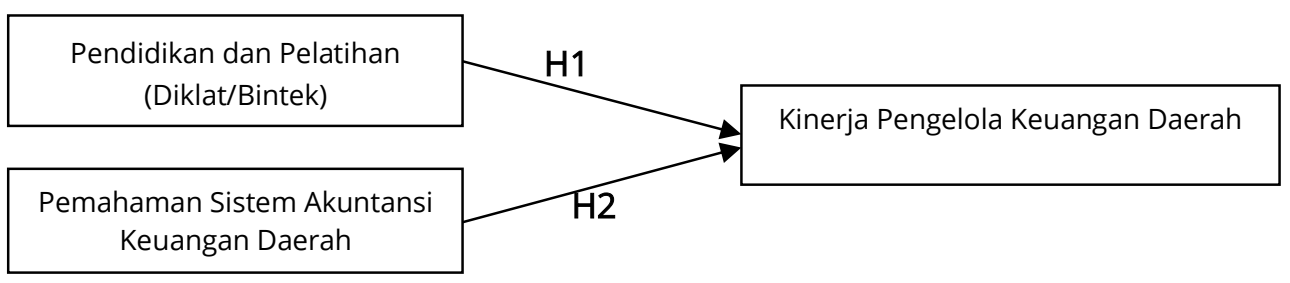

\section{METODE PENELITIAN}

\section{Jenis Penelitian}

Penelitian kausal (Causal Research) yang digunakan untuk mempelajari bagaimana hubungan diantara sejumlah variabel, beserta permasalahan yang sudah dirumuskan secara tajam dalam bentuk keterkaitan antara variabel satu dengan variabel lainnya. Jenis ini dapat juga dikatakan sebagai penelitian kuantitatif yaitu penelitian dengan memperoleh data yang berbentuk angka atau data yang diangkakan (Sugiyono, 2016). Jenis data yang digunakan terhadap penelitian ini adalah data primer yang didapat dari kuesioner yang akan dibagikan.

\section{Populasi dan Sampel}

Populasi dalam penelitian ini adalah seluruh pengelola keuangan yang ada pada semua Satuan Kerja Perangkat Daerah (SKPD) di Kota Bengkulu. Pengambilan sampel dilakukan dengan menggunakan metode purposive sampling, yaitu teknik penentuan sampel dengan pertimbangan tertentu (Sugiyono, 2016). Penentuan kriteria sampel yaitu pengelola keuangan pada SKPD yang telah melakukan aktivitas pengelolaan keuangan daerah di atas satu tahun, dengan harapan mereka memang telah mempunyai pengalaman.

\section{Metode Analisi Data}

Analisis data dilakukan dengan menggunakan bantuan program komputer yaitu SPSS (statistical package for social science 16.0 for Windows). Analisis regresi linier berganda digunkan untuk menganalisis secara langsung pengaruh variabel independen yang terdiri dari: Pendidikan dan pelatihan (Diklat/Bintek), Kecerdasan emosional, Kecerdasan spiritual, Pemahaman sistem akuntansi keuangan daerah, Komitmen organisasi terhadap variabel dependen yaitu Kinerja pengelola keuangan daerah. Pengujian ini dilakukan dengan persamaan sebagai berikut:

$$
Y=\alpha+\beta 1 X 1+\beta 2 X 2+e
$$

Dimana: $\quad Y=$ Kinerja Pengelola Keuangan Daerah (KPKD)

$\boldsymbol{\alpha}=$ Konstanta

$\beta=$ Koefisien Regresi

X1 = Pendidikan dan Pelatihan (Diklat/Bimtek).....(P \& P)

X2 = Pemahaman Sistem Akuntansi Keuangan Daerah....(PSAKD)

$\mathrm{e}=$ Eror 


\section{HASIL DAN PEMBAHASAN}

Hasil

\section{Tingkat Pengembalian Kuesioner}

Pada penelitian ini, data diperoleh dengan cara mengantarkan langsung kuesioner yang digunakan kepada para responden di semua Satuan Kerja Perangkat Daerah (SKPD) pemerintah Kota Bengkulu (33 SKPD). Responden dalam penelitian ini adalah pengelola keuangan pada SKPD yang telah melakukan aktivitas pengelolaan keuangan daerah di atas satu tahun, dengan harapan mereka memang telah mempunyai pengalaman. Kuesioner yang didistribusikan kepada responden sebanyak 90 kuesioner (rata-rata 3 kuesioner untuk masing-masing SKPD). Dari sebanyak 90 kuesioner yang didistribusikan hanya sebanyak 65 kuesioner atau sebesar 72,22\% yang kembali kepada peneliti. Dari sebanyak 65 kuesioner yang kembali hanya sebanyak 60 kuesioner, sehingga dipakai dalam penelitian ini, dikarenakan sebanyak 5 kuesioner dari responden terdapat jawaban pernyataan yang masih kosong, sehingga tidak bisa diolah.

\section{Pengujian Hipotesis}

Sebelum melihat pengujian hipotesis untuk setiap variable yang diuji, sebagai syarat dalam pengujian analisis regresi, diharuskan melihat terlebih dulu hasil pengujian terhadap nilai $\mathrm{F}$ dalam output regresi. Untuk mengetahui apakah model regresi yang ada dalam penelitian fit atau tidak, maka dilihat nilai F. apabila nilai F signifikan (sig di bawah 0,05) maka itu menunjukkan bahwa model penelitian adalah fit. Tabel 1. menunjukkan hasil pengujian bahwa nilai $F$ signifikan pada 0,000 sehingga model persamaan regresi dalam penelitian ini adalah fit.

Selanjutnya untuk melihat berapa besar pengaruh variabel independen terhadap variabel dependen, maka dapat dilihat nilai Adjusted $R$ Square. Hasil pengujian menunjukkan nilai Adjusted $R$ Square berada pada nilai 0,537. Ini berarti variabel independen mampu menjelaskan variabel dependen dalam penelitian ini adalah sebesar $53,70 \%$.

Tabel 1. Hasil Pengujian Hipotesis

\begin{tabular}{|c|c|c|c|c|}
\hline \multirow{2}{*}{ Variabel } & & & & \multirow{2}{*}{$\begin{array}{c}\text { Konfirmasi } \\
\text { Hipotesis }\end{array}$} \\
\hline & Nilai Koefisien & t- statistik & Sig. & \\
\hline Konstanta & $-2,007$ & $-0,369$ & 0,714 & \\
\hline Pendidikan dan pelatihan & 0,151 & 2,536 & 0,014 & Diterima \\
\hline $\begin{array}{ll}\text { Pemahaman } & \text { Sistem } \\
\text { Akunt Keu Daerah } & \end{array}$ & 0,206 & 2,603 & 0,012 & Diterima \\
\hline R Square & 0,486 & & & \\
\hline Adjusted $R$ Square & 0,427 & & & \\
\hline$F$ & 11,441 & & & \\
\hline Sig & 0,000 & & & \\
\hline
\end{tabular}

Sumber: Data diolah, 2019

Pengujian hipotesis dalam penelitian ini menggunakan analisis regresi linear berganda (multiple regression analysis) dimana di peroleh hasil:

$Y=-2,007+0,151 X_{1}+0,206 X_{2}+e$

Rumus diatas dapat dijelaskan sebagai berikut:

a) Besarnya Nilai konstanta yaitu -2,007 menunjukkan dalam variabel pendidikan dan pelatihan (diklat/bimtek), kecerdasan emosional, kecerdasan spiritual, pemahaman 
sistem akuntani keuangan daerah dan komitmen organisasi jika nilainya 0 maka kinerja pengelola keuangan daerah memiliki tingkat kinerja sebesar -2,007.

b) Nilai koefisien pendidikan dan pelatihan (diklat/bimtek) $\left(X_{1}\right)$ sebesar 0,151 dengan nilai positif. Hal ini berarti bahwa setiap peningkatan pendidikan dan pelatihan (diklat/bimtek) sebesar 1 kali maka kinerja pengelola keuangan daerah akan meningkat sebesar 0,151 dengan asumsi variabel yang lain konstan.

c) Nilai koefisien pemahaman sistem akuntani keuangan daerah $\left(X_{2}\right)$ sebesar 0,206 dengan nilai positif. Hal ini berarti bahwa setiap peningkatan pemahaman sistem akuntani keuangan daerah sebesar 1 kali maka kinerja pengelola keuangan daerah akan meningkat sebesar 0,206 dengan asumsi variabel yang lain konstan.

\section{Pembahasan}

\section{Pengaruh Diklat/Bimtek Terhadap Kinerja Pengelola Keuangan Daerah}

Berdasarkan hasil pengujian hipotesis pertama didapat hasil bahwa Pendidikan dan Pelatihan (diklat/bimtek) berpengaruh positif terhadap kinerja pengelola keuangan daerah. Ini berarti bahwa pendidikan dan pelatihan (diklat/bimtek) yang diikuti oleh para pengelola keuangan derah selama ini pada pemerintah daerah kota Bengkulu telah mampu meningkatkan kinerja para pengelola keuangan daerah itu sendiri. Pengetahuan yang mampu merubah dan meningkatkan kemampuan para pengelola keuangan untuk bekerja lebih baik, penuh tanggungjawab, tepat waktu dalam menyelesaikan tugas, serta mempunyai kemampuan bekerja dalam tim untuk mencapai tujuan pemerintahan, yaitu mensejahterakan masyarakat.

Hasil penelitian ini sejalan dengan penelitian yang pernah dilakukan oleh Goni (2013), Sihite (2012), Harsono (2009), Feriyanto (2005), Abidin (2003), Rahim (2006) yang semuanya membuktikan bahwa pendidikan dan pelatihan (diklat/bimtek) berpengaruh dalam peningkatan kinerja pegawai dan organisasi. Semakin baik dan sering para pengelola keuangan derah mengikuti pendidikan dan pelatihan (diklat/bimtek) dalam bidang pengelolaan keuangan daerah maka akan semakin mampu meningkatkan kompetensi mereka dalam melaksanakan tugas dan tanggungjawab yang diberikan, pada akhirnya akan meningkatkan kinerja diri mereka sendiri dan kinerja organisasi secara keseluruhan. Hasil penelitian ini sejalan dengan konsep Teori stewardship dimana pada pelayan (pengelola keuangan daerah) yang memiliki perilaku dimana dia dapat dibentuk (melalui pendidikan dan pelatihan) untuk meningkatkan kemampuannya agar selalu dapat bekerjasama dalam organisasi, tepat waktu dalam bekerja, mempunyai tanggungjawab dalam melaksanakan tugas.

Berdasarkan hasil penelitian ini diharapkan pemerintah daerah kota Bengkulu untuk terus berupaya meningkatkan kemampuan para pengelola keuangan daerah melalui pemberian pendidikan dan pelatihan (bimtek/diklat) yang terstruktur dan bertanggungjawab. Perubahan aturan perundang-undangan yang terus terjadi dalam menciptakan good governance dalam pengelolaan keuangan daerah membutuhkan kecepatan responden dari pemerintah daerah mempersiapkan para pengelola keuangan daerah untuk mengikuti dan memahami berbagai perubahan tersebut. 


\section{Pengaruh Pemahaman Sistem Akuntansi Keuangan Daerah Terhadap Kinerja} Pengelola Keuangan Daerah

Berdasarkan hasil pengujian hipotesis keempat didapat hasil bahwa pemahaman pengelola keuangan daerah terhadap sistem akuntansi daerah mempunyai pengaruh positif (+) terhadap kinerja pengelola keuangan daerah. Ini berarti pemahaman sistem akuntansi keuangan daerah selama ini dalam pengelolaan keuangan daerah telah mampu meningkatkan kemampuan pengelola keuangan dalam melaksanakan tugas dan tanggungjawab sehingga pada akhirnya meningkatkan kinerjanya. Pemahaman yang baik akan berbagai prosedur akuntansi yang ada dalam pengelolaan keuangan daerah oleh para pengelola keuangan sesuai dengan aturan perundang-undangan yang berlaku akan membuat para pengelola keuangan mampu menjalankan proses manajemen keuangan dengan lebih. Tugas dan tanggungjawab yang dijalankan dengan baik akan memberikan dampak positif terhadap kinerja secara keseluruhan.

Hasil penelitin ini sejalan dengan Mardiasmo (2009) bahwa untuk dapat menghasilkan laporan keuangan yang relevan, handal, dan dapat dipercaya, pemerintah harus memiliki sistem akuntansi yang handal. Hasil penelitian juga sejalan dengan penelitian Erwin (2016), Rohman (2009), Rajana (2009), Ratih (2012), Astuti (2008), dan Sari (2013) yang menemukan bahwa implementasi sistem akuntansi keuangan daerah dapat meningkatkan kinerja pengelola keuangan dan akhirnya meningkatkan kinerja organisasi secara keseluruhan. Penelitian ini mendukung teori stewardship yang menggambarkan pengelola keuangan daerah sebagai steward akan terus memperbaiki dirinya dengan meningkatkan kompetensi dirinya melalui pemahaman yang baik akan sistem akuntansi keuangan daerah (Simda) sebagai sarana dalam proses dan penyajian informasi keuangan pemerintah daerah. Simda adalah sistem yang disediakan oleh pemerintah pusat sesuai dengan aturan yang ada untuk diterapkan di pemerintah daerah guna mempermudah pengelola keuangan daerah dalam pelaksanaan transaksi keuangan daerah dan pertanggungjawaban keuangan.

Hasil penelitian ini memberikan pemahaman kepada pemerintah daerah untuk terus meningkatkan kemampuan pengelola keuangan daerah dalam memahami sistem akuntansi keuangan daerah yang ada sesuai dengan aturan perundang-undangan yang ada. Sistem akuntansi keuangan daerah adalah sebuah sistem berbasis aplikasi teknologi yang dikembangkan untuk mendukung tercapainya akuntabilitas bagi pemerintah daerah baik ditingkat pelaporan Satuan Kerja Pengelola Keuangan Daerah (SKPKD) ataupun ditingkat akuntansi di Satuan Kerja Perangkat Daerah (SKPD). Pemerintah daerah terus berupaya memberikan pengetahuan kepada pengelola keuangan daerah sehingga mereka mampu dalam penyusunan perencanaan dan penganggaran, pelaksanaan dan penatausahaan APBD, serta pertanggungjawaban dan pelaporan APBD. Bagi para pengelola keuangan daerah untuk terus meningkatkan kemampuannya dalam memahami sistem akuntansi keuangan daerah sesuai dengan perkembangan yang ada berdasarkan aturan perundang-undangan yang berlaku. 


\section{KESIMPULAN DAN SARAN}

\section{Kesimpulan}

1. Pendidikan dan pelatihan (bimtek/diklat) terbukti mempunyai pengaruh positif terhadap kinerja pengelola keuangan daerah. Pendidikan dan pelatihan yang selama ini diikuti oleh para pengelolaan keuangan dalam peningkatan kemampuannya dalam pengelolaan keuangan daerah telah mampu meningkatkan kinerjanya dalam pengelolaan keuangan pada SKPD pemerintah daerah kota Bengkulu.

2. Pemahaman terhadap sistem akuntansi keuangan daerah terbukti mempunyai pengaruh positif terhadap kinerja pengelola keuangan daerah. Sistem akuntansi keuangan daerah berdasarkan aturan perundang-undangan yang dipahami oleh pengelola keuangan telah mampu meningkatkan kinerjanya dalam pengelolaan keuangan pada SKPD di pemerintah daerah kota Bengkulu.

\section{Saran}

1. Peneliti selanjutnya dapat melakukan perluasan terhadap responden dengan mengupayakan tingkat pengembalian kuesioner yang tinggi sehingga responden yang direncanakan dari awal penelitian mampu semuanya didapatkan.

2. Peneliti melakukan perbaikan terhadap cara menyiapkan pernyataan dalam kuesioner penelitian sehingga tidak menimbulkan salah tafsir dalam memberikan jawaban. Kemungkinan lagi data juga dilakukan pengawasan dan pendampingan dalam proses pengisian sehingga data yang diberikan benarbenar kondisi riil di lapangan sehingga informasi yang didapat tidak bias.

\section{DAFTAR PUSTAKA}

Achmad S. Ruky, 2006. Sistem Manajemen Kinerja, Gramedia Pustaka Utama, Jakarta.

Abidin, Zainal, 2003. Hubungan Karakteristik Individu dan Pendidikan Latihan dengan Kinerja Pegawai Dinas Pendidikan Nasional Kota Lubuklinggau, Tesis. Program MM Universitas Bengkulu, tidak dipublikasikan.

Anwar, Prabu, 2002. Reformasi Administrasi, PT. Grasindo, Jakarta.

Astuti, Maulidah Tri, 2008. Pengaruh Penerapan Sistem Informasi Akuntansi Terhadap Kinerja Individu, Brawijaya. Malang.

Azhar, Susanto. 2007. Sistem Informasi Akuntansi. T. Lingga Jaya, Jakarta.

As'ad, Moch. 2003. Manajemen Personalia dan Sumber Daya Manusia, BPFE, Yogyakarta.

Armstrong, Michael. 1998. Performance Management: The New Realities, Institute Of Personel And Development, New York.

Bastian, Indra. 2010. Akuntansi Sektor Publik: Suatu Pengantar. Jakarta: Erlangga.

Berhardin, H., 2000. Human Resources Management, McGraw Hill, New York.

Boyatzis, R,E, Ron, S. 2001. Unleashing the Power of Self Directed Learning,. Case Western Reserve University, Cleveland, Ohio, USA. 
Davis, F.D. dan Venkatesh, V. 2000. A Theoretical Extension of The Technology Acceptance Model: Four Longitudinal Field Studies. Management Science, 46(2), 186-204

Davis, J., and Donaldson, L., 1994. The Theory of Stewarship, Working Paper. University of Notre Dame.

Devis, K., 1996. Human Resources Management, Prentice Hall, New York.

Dominggus, Pirade, $d k k$. 2013. Pengaruh Penggunaan Sistem Informasi Pengelolaan. Keuangan Daerah (SIKPD) Terhadap Kinerja Pegawai di Kabupaten Tana. Toraja. Jurnal Analisis, vol. 2 no 2, hal 182-193, Universitas Hasanudin.

Djauhari, H. Nurdin, 2008. Hubungan Antara Pendidikan-Latihan dan Masa Kerja Dengan Kinerja Pejabat Penyusun Rencana Anggaran Satuan Kerja (RASK) di Lingkungan Pemerintah Kota Pagaralam. Tesis Program MM Unib, tidak dipublikasikan.

Erwin. 2016. Pengaruh Penerapan Sistem Informasi Manajemen Keuangan Daerah (Simda), Sistem Pengendalian Intern, Kompetensi Aparatur Dan Ketaatan Standar Akuntansi Pemerintahan Terhadap Kualitas Laporan Keuangan Pemerintah Kabupaten/Kota. Tesis Pascasarjana Univ Khairun Ternate.

Estiningsih, Retno Utami, 2008. Penerapan Learning Organizations Bagi pengembangan SDM Organisasi. http.www.tabloit-tawon com.

Feriyanto, John, 2005. Hubungan Karakteristik Individu dan Pendidikan Pelatihan dengan Kinerja Lurah di lingkungan Kecamatan Curup Kabupaten Rejang Lebong, Tesis. Program MM Unib, tidak dipublikasikan.

Ghozali, Imam, 2013. Aplikasi Analisis Multivariat dengan Program IBM SPSS 21. Edisi 7, Penerbit Universitas Diponegoro, Semarang.

Halim, Abdul. 2008. Auditing : Dasar-dasar Audit Laporan Keuangan.Unit Penerbit dan Percetakan STIM YKPN. Yogyakarta

-. 2007. Akuntansi Sektor Publik Akuntansi keuangan daerah, Edisi Revisi, Jakarta, Salemba Empat.

Jogiyanto, 2010. Analisis dan Desain Sistem Informasi, Edisi IV, Andi Offset, Yogyakarta.

Kurnia, Nia, 2005. Pengaruh Latar Belakang Tingkat Pendidikan terhadap Kinerja Aparatur Pemerintah Daerah, Universitas Pendidikan Indonesia, Bandung.

Mahsun, Mohamad, 2006. Pengukuran Kinerja Sektor Publik,. Penerbit BPFE, Yogyakarta

Mardiasmo. 2009. Akuntansi Sektor Publik, Yogyakarta: ANDI.

Martin. 2000. Aplikasi EQ Based HR Management System. Majalah Manajemen.

Marlia, Harapan. 2014. Pengaruh Tingkat Pendidikan Pengalaman Kerja, Gaji dan Komitmen Organisasi terhadap Kinerja Pengelola Keuangan pada Satuan Kerja Perangkat Daerah (SKPD) Kabupaten Lebong. Universitas Bengkulu

Mahmudi. 2007. Manajemen Kinerja Sektor Publik. Yogyakarta: UPP. STMYKPN. Martoyo, Susilo. 2000. Manajemen Sumber Daya Manusia. Yogyakarta: BPFE Mondy, R Wayne. 2008. Manajemen Sumber Daya Manusia. Jakarta: Erlangga.

Mowday, R. T., Steers, R. M.,\&Porter, L.W. 1979,. The measurement of organizational commitment. Journal of Vocational Behavior, 14, 224-247.

Mulyadi. 2001. Sistem Akuntansi. Edisi Tiga. Jakarta : Salemba Empat. 
Muth, Meilinda M, and Lex D, 1998. Stewarship Theory and Board Structure: a contingency approach. Scholarly Research and Theory Papers, Volume 6 Nomor 1. pp 5-28.

Nasarudin, Fadliah. 2008. Pengaruh Pendidikan, Pelatihan dan Pengalaman Kerja Terhadap Kualitas Penyajian Informasi Akuntansi Pada Bank Negara Indonesia Tbk. Jurnal Ichsan Gorontalo, Volume 3 Nomor 1. Februari-April 2008.

Nasution, 2005, Total Quality Management, PT Gramedia Pustaka Utama: Jakarta.

Nordiawan, Deddi dan Ayuningtyas Hertianti. 2010. Akuntansi Sektor Publik. Edisi Kedua. Jakarta: Salemba Empat.

Putri, Gustika Yolanda. 2013. Pengaruh Komitmen Organisasi dan Sistem Pengendalian Intern Terhadap Kinerja Manajerial SKPD (studi empiris pada satuan kerja perangkat daerah kota Padang). Jurnal Akuntansi, Vol. 1 No. 1 hal 1-10.

Raharjo, Eko. 2007. Teori Agensi dan Teori Stewardship Dalam Perspektif Akuntansi. Fokus Ekonomi. Vol. 2 No. 1, pp I 37-146.

Rajana HRP, Junita P. 2009. Pengaruh Pemahaman SAP, Pendidikan, dan Pelatihan Terhadap Penyusunan Laporan Keuangan SKPD. Tesis Tidak Dipublikasikan, USU. Medan.

Ratih, Asri Eka, 2012. Pengaruh Pemahaman Sistem Akuntansi Keuangan Daerah, Penatausahaan Keuangan Daerah, dan Pengelolaan barang Milik Daerah Terhadap Kinerja SKPD Pada Pemerintahan Provinsi Kepulauan Riau. Tesis Tidak Dipublikasikan, Sekolah Pasca Sarjana, Sumatera Utara.

Robert, Bacal, 2005. Performance Management, Gramedia Pustaka Utama, Jakarta.

Rohman, Abdul, 2009. Pengaruh Implementasi Sistem Akuntansi, Pengelolaan Keuangan Daerah Terhadap Fungsi Pengawasan dan Kinerja Pemerintah Daerah (Studi Pada Pemda di Jawa Tengah). Jurnal Akuntansi dan Bisnis, Volume 9, Nomor 1,

Republik Indonesia, 2004. Undang-Undang Nomor 32 Tahun 2004 Tentang Pemerintahan Daerah.

2004. Undang-Undang Nomor 33 Tahun 2004 Tentang Perimbangan Keuangan antara Pemerintah Pusat dan Daerah.

Sari, Erna, 2013. Pengaruh Pemahaman Sistem Akuntansi Pemerintahan, dan Penatausahaan Keuangan Daerah Terhadap Kinerja Pengelola Keuangan Daerah. Jurnal Fairness, Volume 3, Nomor 3, 19-29.

Sihite, Tiurlina Hasmawati. 2012. Pengaruh Pendidikan Dan Pelatihan (Diklat) Serta Motivasi Terhadap Kinerja Pegawai Di Sekretariat Daerah Kabupaten Tapanuli Tengah. Tesis. Program Magister Manajemen Program Pascasarjana Universitas Terbuka Jakarta.

Sugiyono. 2016. Metode Penelitian Kuantitatif, Kualitatif dan R\&D. Bandung: PT Alfabet.

Supratman, Acu, 2005. Hubungan Pendidikan dan Pelatihan dan Motivasi dengan Produktivitas Kerja Manajer Tingkat Pertama pada Kantor Pusat PT. Kereta Api Indonesia. Tesis, Jurusan Pendidikan Ilmu Pengetahuan Sosial, Universitas Pendidikan Indonesia, Bandung.

Widjajanto, Nugroho. 2001. Sistem Informasi Akuntansi. Erlangga: Jakarta

Wilkinson, J. W. 1992. Accounting and Information Systems. John Wiley \& Sons, Inc 
www.BPKP.go.id

Zahara, Naily, 2008. Pengaruh Pelaksanaan Program Diklat, Pengalaman Kerja, Terhadap Kinerja Karyawan Bagian Keperawatan RSUD. RAA. Soewondo Pati. Univ Muhammadiyah-Surakarya 